\title{
Agglomeration economies, accessibility, and the spatial choice behavior of relocating firms
}

\author{
Michiel de Bok \\ Frank van Oort \\ Significance b.v. ${ }^{\text {a }} \quad$ Utrecht University
}

\begin{abstract}
A growing body of empirical urban economic studies suggests that agglomeration and accessibility externalities are important sources of the uneven distribution of economic activities across cities and regions. At the same time, little is known about the importance of agglomeration economies for the actual location behavior of firms. This is remarkable, since theories that underlie agglomeration economies are microeconomic in nature. In a case study of the Dutch province of South Holland, we analyze micro-level data to determine the extent to which relocation decisions are dependent on accessibility and agglomeration externalities when controlling for firm characteristics. These externalities are measured with location attributes for both own-sector localization and urbanization economies and for proximity to transport infrastructures. The results confirm that firm relocation behavior is affected much more by firm-level attributes (size, age, and growth rate) than by agglomeration and accessibility attributes. Still, accessibility and agglomeration are significantly attached to firm relocations, though their effects vary over sectors. Own-sector and generalized external economies are more important for a firm's location choices than proximity to transport infrastructure.
\end{abstract}

Keywords: Firm location; Discrete choice modeling; Accessibility; Urban economics

\section{Introduction}

From the 1980s onwards, there has been a renewed interest in economic geography generally and economic agglomeration particularly. This interest can be ascribed mainly to the fact that orthodox economics proper provides insufficient explanations for the variations in the wealth and poverty of cities and regions. Since the 1990s, a new family of models has been developed, following the seminal paper by Krugman (Krugman 1991). This new theoretical approach, generally known as New Economic Geography (NEG) models, takes space explicitly into account by introducing not only specific location factors explaining the distribution of economic activities, but also imperfect competition and economies of scale. Simultaneously, a large body of empirical literature has emerged in the field of regional science and urban economics that examines the question of whether spatial circumstances give rise to agglomeration economies-external economies from which firms can benefit through co-location-that endogenously induce localized economic growth (Glaeser et al. 1992; Rosenthal and Strange 2003). Many of these empirical studies convincingly show that agglomeration economies may be

\footnotetext{
adebok@significance.nl
}

one source of the uneven distribution of economic activities and economic growth across cities and regions. In their survey of this empirical literature on the benefits of agglomeration, Rosenthal and Strange (2004) point out that the elasticity of productivity to city and industry size typically ranges between three and eight percent. The effect of agglomeration economies on localized firm behavior can be expected to differ, however, across sectors, space, and time (McCann and Folta, 2008; (Groot et al. 2009). At the same time, little is known about the importance of agglomeration economies for the location decisions of individual firms (Acs and Armington 2004; Martin et al. 2008). As most empirical research on agglomeration uses aggregated data with cities or city-industries as basic reference unit, ${ }^{1}$ these studies provide only limited insights into the effect of agglomeration economies on firms' location behavior and subsequent performance. Although this scarcity of firm-level evidence in the locational choice and agglomeration literature can be ascribed to data limitations and confidentiality restrictions, its absence is nevertheless disturb-

\footnotetext{
${ }^{1}$ There is a growing literature on the relation of individual firm productivity and productivity growth to agglomeration circumstances (for overviews, see Rosenthal and Strange 2003 and Duranton and Puga 2004),but empirical studies determining locational decisions of firms remain scarce (Henderson 2007; Holl 2004b).
}

Copyright 2011 Michiel de Bok and Frank van Oort.

Licensed under the Creative Commons Attribution - NonCommercial License 3.0. 
ing, as the theories - like the New Economic Geography that underlie agglomeration economies are microeconomic in nature (Martin et al. 2008). In other words, agglomeration economies do not directly foster regional economic growth, but do so only indirectly through their effect on firm performance and location decisions (Neumark et al. 2006).

This new theoretical approach, generally known as New Economic Geography (NEG) models, takes space explicitly into account by introducing not only specific location factors explaining the distribution of economic activities, but also imperfect competition and economies of scale. Simultaneously, a large body of empirical literature has emerged in the field of regional science and urban economics that examines the question of whether spatial circumstances give rise to agglomeration economies-external economies from which firms can benefit through co-location-that endogenously induce localized economic growth (Glaeser et al. 1992; Rosenthal and Strange 2003). Many of these empirical studies convincingly show that agglomeration economies may be one source of the uneven distribution of economic activities and economic growth across cities and regions. In their survey of this empirical literature on the benefits of agglomeration, Rosenthal and Strange (2004) point out that the elasticity of productivity to city and industry size typically ranges between three and eight percent. The effect of agglomeration economies on localized firm behavior can be expected to differ, however, across sectors, space, and time (McCann and Folta, 2008; (Groot et al. 2009). At the same time, little is known about the importance of agglomeration economies for the location decisions of individual firms (Acs and Armington 2004; Martin et al. 2008). As most empirical research on agglomeration uses aggregated data with cities or city-industries as basic reference unit $^{2}$ these studies provide only limited insights into the effect of agglomeration economies on firms' location behavior and subsequent performance. Although this scarcity of firmlevel evidence in the locational choice and agglomeration literature can be ascribed to data limitations and confidentiality restrictions, its absence is nevertheless disturbing, as the theories - like the New Economic Geography - that underlie agglomeration economies are microeconomic in nature (Martin et al. 2008). In other words, agglomeration economies do not directly foster regional economic growth, but do so only indi-

\footnotetext{
${ }^{2}$ There is a growing literature on the relation of individual firm productivity and productivity growth to agglomeration circumstances (for overviews, see Rosenthal and Strange 2003 and Duranton and Puga 2004), but empirical studies determining locational decisions of firms remain scarce (Henderson 2007; Holl 2004b).
}

rectly through their effect on firm performance and location decisions (Neumark et al. 2006).

The present paper contributes to this discussion in two ways. First, this paper applies discrete (spatial) choice simulation techniques to distinguish between the roles of individual firm characteristics on the one hand and agglomeration externalities on the other, in explaining firm relocation decisions. In particular, the literature on industrial organization stresses the importance of firm internal characteristics, such as age and size, in explaining firm location behavior (Carroll and Hannan 2000), while the urban economic literature focuses on the role of localized externalities. Second, we introduce accessibility externalities of firms alongside agglomeration externalities. Although agglomeration externalities are generally hypothesized to come in the form of sector- specific (localization) advantages, inter-sectoral diversity (Jacobs') advantages, and general (urbanization) advantages (Duranton and Puga 2004), it is often argued that a firm's physical accessibility in relation to other sites and locations within the urban region comprises a distinct local advantage (Geurs and van Wee 2004). Agglomeration and accessibility are intertwined, as economies of distance and the scale in the transportation of goods and information are important features of the agglomeration of economic activity. ${ }^{3}$ Section 2 provides a concise review of these literatures, and each subsection (on firm-internal attributes, agglomeration externalities, accessibility externalities, and keep-factors) concludes with the formulation of testable hypotheses regarding firm relocations.

We then use longitudinal firm data from the Dutch province of Zuid-Holland to disentangle the individual from contextual effects of agglomeration and accessibility, working within a framework in which observed firm relocations are analyzed with two models. We first analyze the relocation probability of firms using a binary regression model. Next, the observed location decisions and the underlying location preference of firms are analyzed with competing destinations models (Fotheringham 1983). The location choice models rely on firm attributes as well as accessibility and agglomeration attributes, including logsum accessibility measures of labor market and supplier accessibility, and proximity measures of the distance to highway onramps and train stations. Following the urban economic literature, levels of (own-sector) specialization, (generalized) urbanization and sector diversification of locations are introduced as agglomeration economies. These measures are computed from the composition of the firm pop-

\footnotetext{
${ }^{3}$ By modeling firm-level location decisions instead of regional aggregates, we avoid a common endogeneity problem related to the initial measurement levels of cities and regions.
} 
ulation within range bands that can be reached from a location over the road network (Rosenthal and Strange 2004). Section 3 introduces these (sectorally specific) models and the data, and section 4 discusses the estimation results. From these, we conclude that firm relocation behavior is affected much more by firm-level attributes than by external attributes. In turn, within the external attributes, firms' location choices are more profoundly affected by own-sector and generalized agglomeration economies than by proximity to transport infrastructure.

\section{Conceptual background and research hypotheses}

If externalities are important for growth, they will influence firms' location decisions. In particular, when knowledge, labor, and supplies are not easily exchanged from a distance but instead spill over locally, firms tend to locate in proximity to each other in order to capitalize on the knowledge and human capital stock in neighboring firms (Koo 2005). However, very little is known about the impact of location on actual firm performance and relocation behavior. Studies on entrepreneurship and industrial dynamics often overlook the role of location (Beugelsdijk 2009; Maskell 2001; Parker 2005; Taylor and Asheim 2001). Beugelsdijk (2009) and Audretsch and Dohse (2007) indicate that the reasons for this omission are both conceptual and empirical in nature. At the conceptual level, there are hardly any models that link the performance of individual firms to regional (knowledge and human capital) characteristics. At the empirical level, analyzing firm location and growth (in a spatial context) requires longitudinal data at the establishment or enterprise level, which are often not available. In this section, we discuss firm-level theories and attributes, as well as agglomeration and accessibility externalities as drivers of economic development and the location decisions of firms. We will pay special attention to the conceptual interaction between these micro-level and spatial-context-level attributes.

\subsection{From firm level attributes to externalities}

In the industrial organization and organizational ecology literatures, firm-internal economies of scale that lead to growth and relocation propensities are predominantly related to firm size and firm age (Carroll and Hannan 2000; Jovanovic 1982). This is especially the case in the 'resource-based' view of the firm, which provides a comprehensive firm-based framework for analyzing firm-region interactions (Maskell 2001; Taylor and Asheim 2001). According to this view, a firm is a bundle or collection of unique resources, competencies, and capabilities. Those firms with superior bundles of these assets will earn rents. This view suggests that firm capabilities that are valuable, rare, and inimitable will determine long-term competitive advantages. ${ }^{4}$ Recently, the resource-based view of the firm has been extended with the idea that knowledge should be considered as a significant resource of the firm (Grant 1996). Heterogeneous knowledge bases and capabilities among firms are, then, among the main determinants of superior corporate performance. Although firms thus strive to make their internal (knowledge) capabilities valuable, there are potentially beneficial factors that are not (completely) internal to the individual firm but (also) lie outside its boundaries. From a resource-based view of the firm, firms can also profit from 'externalities'. Advantages can come from leveraging resources in a complex network of relationships. As no single firm can have all the requisite capabilities inside its corporate boundaries, there is supposed to be a localized (external) collectivity that does.

The impact of these 'localized externalities' may not be the same for all types of firms. Firm-specific characteristics may, therefore, precondition whether a given firm can profit from externalities. Cohen and Levinthal (1989) argue that firms must develop an internal core knowledge base so that they can understand external resources and know how to apply them to the firm's specific needs. Age can be interpreted as differentiating in the amount of experience firms have, for instance in learning from own experience (Jovanovic 1982). Older firms, therefore, may have less need to tap into external resources than young ones. This view fits in with the idea that routines and learning processes may become ossified, implying that firm performance and external interaction tends to decline as the firm evolves over its life cycle (Audretsch and Dohse 2007). Like age, size is often hypothesized as important for growth, as size can represent scale advantages that can be positively related to productivity (Carroll and Hannan 2000). Like young firms, small firms wanting to generate their own absorptive capacity and knowledge capital will be limited by scale and time. Larger firms have more opportunities than their smaller counterparts to invest in knowledge sources themselves. A considerable number of empirical studies support the view that larger and older firms are less likely to achieve strong growth performance due to the ossification of

\footnotetext{
${ }^{4}$ This perspective is based on the work of Penrose (1959), elaborated by Teece (1982).

${ }^{5}$ This suggests a link with the knowledge-spillover theory of localization externalities in agglomeration theory (see the next section).
} 
routines and learning processes. Recent empirical findings of Audretsch and Dohse (2007) and Raspe and van Oort (2008) indicate that age and size indeed have a negative effect on firmlevel growth.

Finally, two firm-level factors are important. First, firms that showed considerable growth dynamics in earlier periods (either negatively or positively) usually have a larger incentive to relocate-either to a larger production space when growth is positive or to a smaller production space when growth is negative $^{6}$ (van Oort 2004). Second, the type of industry a firm belongs to can be relevant for firm performance and hence for relocation, since industries experience different development paths and cyclical influences (Neffke 2009). Industry-specific characteristics capture various technology and knowledge dimensions, such as technological opportunity, appropriability regimes, or the emergence of dominant designs along the technology life cycle. But some industries also benefit more from geographical circumstances than their counterparts in other industries (Henderson 2007). Producer service firms are-because of the absence of large sunk costs-often hypothesized to be more mobile than manufacturing, distribution and consumer services firms (Holl 2004a; van Dijk and Pellenbarg 2005; van Oort 2004; van Oort and Ponds 2007). ${ }^{7}$

This suggests the following testable hypotheses on the locational preference of relocating firms:

1. Larger firms are less likely to relocate than smaller firms.

2. Older firms are less likely to relocate than younger firms.

3. Firms that recently faced larger employment changes (either positive or negative) are more likely to relocate.

4. Firms in producer services industries are more likely (able) to relocate than firms in other industries.

\subsection{Agglomeration externalities}

The literature on urban economics emphasizes the importance of agglomeration economies embodied in different types of local sectors and forms of market organization related to a firm's spatial environment (Duranton and Puga 2004). In contrast to firm-internal economies of scale (lower unit production costs with increasing production volume), spatial externalities are externally derived and the firm does not pay any direct costs for them. Marshall (1890) mentions a number of such cost-saving benefits or productivity gains, which frequently are described as localization economies of firms arising from

\footnotetext{
${ }^{6}$ When firms grow negatively, relocation is an unusual strategy unless real-estate costs per employee are very high (Louw, 1996).

${ }^{7}$ Agglomeration externalities stemming from sector-specific concentrations are discussed in the next section.
}

the density of a firm's own sector. First, a sector that is spatially concentrated can exert a pull on (as well as uphold) a large labor pool including workers with specialized training relevant for the industry. This reduces search costs and offers more opportunities for the hiring of employees. The advantage goes two ways, since employees also benefit from having more job opportunities nearby. Second, input sharing leads to externalities that are the result of scale economies in input production for the suppliers. A supplier that has more customers nearby has larger production volumes and lower average unit production costs. Thirdly, agglomerated firms can profit from knowledge spillovers, as geographical proximity to other actors facilitates the diffusion of new ideas or improvements related to products, technology, and organization. Spillover can be produced by ongoing relationships between firms, but also may be a product of job mobility, local epistemic communities, and informal contacts between employees of different firms.

The framework of agglomeration externalities was later expanded with external economies accessible to all companies in a geographical concentration irrespective of the sector concerned. These urbanization externalities derive from the density of the urban economy. According to Isard (1956), the availability of a multi-functional labor pool and the presence of good infrastructure and public facilities support economic growth. Relatively densely inhabited localities are also more likely to accommodate knowledge-generating institutions (such as universities, $\mathrm{R} \& \mathrm{D}$ laboratories, and trade associations), which support the generation and diffusion of knowledge and encourage innovative behavior among firms. Moreover, the presence of a large internal market offers a greater degree of stability and lowers transaction costs for firms. Related to urbanization economies but distinctively different, Jacobs' externalities derive from the diversity or variety of the urban economy. According to Jacobs (Jacobs 1969), it is cities' sector variety, rather than their density, that augments economic growth. A diverse sector structure increases the odds of interaction, generation, replication, modification, and recombination of ideas and applications across different industries (Frenken et al. 2007). Moreover, a diverse industrial structure protects a region from volatile demand and offers the possibility to substitute input. Table 1 summarizes the sources of agglomeration economies in relation to the concepts of localization and urbanization economies.

The concept of externalities formulated by Marshall, Isard, and Jacobs forms a generalized theory of agglomeration that has remained largely unaltered over the years. Despite its considerable size, the empirical literature on agglomeration does not offer a consistent answer to the question of which spa- 
tial externality-circumstance is best able to foster growth. In evaluating studies that used a comparative framework of agglomeration externalities, Rosenthal and Strange (2004) and Groot et al. (2009) report mixed evidence as to which type of externality matters most for economic growth. For the United States, for example, Glaeser et al. (1992) find evidence supporting the notion that diversity fosters employment growth, while Ó hUallacháin and Satterthwaite (1992) find that local specialization and not regional diversity is most important for urban employment growth. Henderson et al. (1995) conclude that, for high-technology industries, both specialization and diversity are conducive to growth. Rosenthal and Strange (2003) find a positive effect of localization, urbanization, and Jacobs' externalities, but also observe that localization economies attenuate quickly with distance. For the Netherlands, van Oort (2004) finds that agglomeration externalities have different effects on economic growth across sectors: whereas local concentration and diversity are positively related to local employment growth in producer services, the opposite appears to be the case in manufacturing; in addition, effects vary across spatial regimes (core/periphery) and formulations of the extent of spatial dependence. Neffke (2009) shows that the life-stage of industries and firms' subsequent technology dependency contribute to the simultaneous significance of localization, Jacobs' and urbanization externalities in cities.

This suggests the following testable hypotheses on the locational preference of relocating firms:

5. Relocating firms seek each other's presence in order to profit from Marshallian localization externalities (firms have a preference for own-sector-specialized locations),

6. Relocating firms benefit from Jacobs' externalities resulting from a rich variety of firms grouped in different industries in the area around the destination location (firms have a preference for sector-diverse locations).

7. Firms prefer locations with favorable urbanization economies and therefore have a preference for locations with high proximity to the labor market or to customers.

\subsection{Accessibility externalities}

Accessibility is usually conceptualized within the framework of urbanization economies (which arise from urban size and density) as benefits stemming from a well-developed infrastructure as well as better accessibility to larger labor pools, potential customers and suppliers, and universities and research institutions. Further, large urban areas have more resources to develop or improve transport infrastructure. Thus, urbanization economies largely refer to benefits on transport or production costs from good market accessibility. Common gravity-based accessibility measures are often used as indicators of this market potential (van Wissen 2000).

Accessibility can thus lead to cost efficiencies and can therefore be regarded as a benefit from spatial externalities ( $\mathrm{Ri}$ etveld 1995). The roles of accessibility and spatial externalities in localized economic development have not often been assessed simultaneously. Measures of proximity to transport infrastructure access points and general gravity-based accessibility measures have been applied in the empirical literature (Leitham et al. 2000; Shukla and Waddell 1991; Waddell and Ulfarsson 2003). However, the transport dimension in itself is often absent or only implicitly represented in agglomeration measures. The structuring influence of transport infrastructure in urban and regional interaction is often only implicitly acknowledged. The majority of empirical studies in the urban economics literature neglects the transport dimension and computes agglomeration measures for aggregated administrative zones that are isolated in space (Rosenthal and Strange 2004). As transport infrastructure is conditioned on spatial interaction, transport infrastructure should be represented explicitly and separated from urban density (Eberts and McMillen 1999; Fingleton and McCann 2007). This means that definitions of accessibility should particularly be at the local or intra-regional level. Earlier contributions by Holl $(2004 a, b)$ show that, controlled for density, investments in physical infrastructure in Portugal are positively related to local economic development. As also discussed with the firmspecific attributes, firms embedded in different sectors have different propensities to move (Holl 2004a; van Dijk and Pellenbarg 2005): producer services and distribution firms are by definition more footloose and are in general more attracted to physical accessible locations than industrial and consumer service firms. This suggests the following testable hypotheses on the locational preference of relocating firms:

8. Firms have preferences for physically accessible locations proximate to highway onramps or train stations.

9. Physical accessibility preferences differ for different sectors: producer services and distribution firms are more attracted to physical accessible locations than industrial and consumer service firms.

\subsection{Keep-factors}

Besides these agglomeration and accessibility circumstances, the empirical literature on firm relocation stresses the particular importance of localized network externalities (of cus- 
Table 1: Types of agglomeration economies (by sources and scope).

\begin{tabular}{lll}
\hline Source & Localization economies & Urbanization economies \\
\hline Labor market pooling & $\begin{array}{l}\text { Access to specialized labor } \\
\text { market }\end{array}$ & $\begin{array}{l}\text { Cost benefits from access to } \\
\text { large labor market }\end{array}$ \\
Input/output sharing & $\begin{array}{l}\text { Access to specialized } \\
\text { suppliers }\end{array}$ & $\begin{array}{l}\text { Cost benefits from access to } \\
\text { customers }\end{array}$ \\
\hline Industry-specific & $\begin{array}{l}\text { Between different industries } \\
\text { or from scientific } \\
\text { environment }\end{array}$ \\
\hline & Marshall externalities & Jacobs'externalities
\end{tabular}

tomers, employees, and suppliers) as keep-factors to explain the relatively small distances involved in typical firm relocations (Holl 2004a; Knoben 2007; van Dijk and Pellenbarg 2005). Location alternatives that are in close proximity are more likely to function as substitutes than more remote alternatives (Fotheringham 1983). Furthermore, the availability of land is one of the most common pull-factors (Holl 2004b; Pellenbarg et al. 2002). This suggests the following hypotheses regarding the locational preference of relocating firms:

10. Firms prefer limited migration distances in order to maintain existing spatial relations with customers and employees.

\section{Modeling framework}

\subsection{The firm migration model}

This analysis is based on a general behavioral model for the location decision of firms in a disaggregated physical environment. We analyze the location choices of individual firms, including the firms' characteristics and the attributes of their locations. The choice alternatives are a set of potential new locations, characterized by the size of the location and by location attributes such as type, degree of localized economic specialization and diversity, and (physical) accessibility.

The migration behavior of an individual firm within this physical environment is regarded as a choice process consisting of a sequence of considerations and decisions. The first decision a firm makes is whether to relocate. This decision is analyzed with a binary logistic regression model similar to the approach in van Wissen (2000) and Bok (2009). The relo- cation probability of a firm is determined by attributes of the firm and of its current location:

$$
\begin{aligned}
& P_{i}^{\mathrm{RP}}(t)= \\
& \frac{1}{1+\exp \left[-\left(\beta_{0 s}^{\mathrm{RP}}+\sum_{\mathrm{n}=1}^{N} \beta_{n}^{\mathrm{RP}} Y_{\mathrm{in}}+\sum_{\mathrm{m}=1}^{M} \beta_{m}^{\mathrm{RP}} X_{\mathrm{jm}}\right)\right]}
\end{aligned}
$$

where $\beta_{0}^{R P}$ is the constant that describes the base in the relocation probability model (RP), $Y_{i n}$ as attribute $n$ of firm $i$ and $X_{j m}$ as attribute $m$ of location $j \cdot \beta_{n}^{R P}$ and $\beta_{m}^{R P}$ are utility coefficients for firm and location attributes respectively.

A representative choice is created for each observed relocation. It is representative for the sector of the relocating firm and its size. These choice sets $L_{i}$ are generated for each relocated firm $i$ by simulating a hierarchical search process, similar to route choice modeling (Bovy 2007). The choice set contains feasible choice alternatives based on individual choice constraints and the awareness space of firms. The observed utility of each alternative in the choice set, $V_{i j}$, is specified with an industry-specific, linearly additive utility function. Thus, the utility of location alternative $j$ for firm $i$ from sector $s$ can be written as:

$$
V_{\mathrm{ij}}=\beta_{0 \mathrm{~s}}^{\mathrm{LC}} d_{\mathrm{ij}}+\sum_{\mathrm{m}=1}^{M} \beta_{\mathrm{rc}}^{\mathrm{LC}} X_{\mathrm{jm}}+\beta_{\mathrm{rs}}^{\mathrm{LC}} Y_{\mathrm{ir}} X_{\mathrm{jr}}, \forall i \in F_{s} .
$$

The utility of location alternative $j$ includes $d_{i j}$, the distance between the current location $i$ and the alternative $j$. Next, it includes a number of location attributes of alternative $j, X_{j m}$, 
such as accessibility and agglomeration. In addition, we test some utility specifications that include interaction terms between location attribute $X_{j r}$ and firm attributes $Y_{i r}$. These interaction terms are used to test whether firms with a specific characteristic have preferences for specific issues, e.g. whether the preference for specialized locations increases with firm size. The parameters of the location choice (LC) model, $\beta_{x s}^{L C}$ are estimated for each sector $s . F_{s}$ is the population of firms in sector $s$.

A particular issue in spatial choice analysis comes from the spatial interdependency of location alternatives that are near each other. The smaller the distance between two alternatives, the more likely they are to serve as substitutes for each other. This affects the choice probability of each individual alternative. The similarity between spatial alternatives is measured with a centrality measure that is a proxy for the spatial cluster membership. Following Fotheringham (1983), this centrality measure $c_{j}$ is based on geographic space:

$$
c_{j}=\left(1 /(K-1) \sum_{k \neq j} w_{k} / d_{\mathrm{kj}}\right),
$$

with $K$ as the number of available firm locations, $d_{k j}$ as the distance between alternatives $k$ and $j$ and $w_{k}$ as the size of alternative $k$. The size of an alternative is specified as the available (unoccupied) floor space or industrial area at a firm location. So, for each alternative that is selected in the consideration set, we compute the centrality relative to all other available location alternatives.

In this application, $c_{j}$ measures the clustering of available locations. In previous studies, centrality is often measured relative to current activities instead of available alternatives (Pellegrini and Fotheringham 2002). In those cases, centrality is similar to agglomeration. We stress that the model measures centrality relative to available firm locations. The influence of agglomeration economies is measured with other measures, presented in the following section.

The competing destinations location choice model for firm $i$ choosing location $j$ out of consideration set $L_{i}$ becomes:

$$
P_{\mathrm{ij} \mid L_{i}}^{\mathrm{LC}}=\frac{\exp \left(V_{\mathrm{ij}}+\theta_{s}^{\mathrm{LC}} \ln \left(c_{j}\right)\right)}{\sum_{k \in L_{i}} \exp \left(V_{\mathrm{ik}}+\theta_{s}^{\mathrm{LC}} \ln \left(c_{k}\right)\right)}, \forall i \in F_{s}
$$

where $V_{\mathrm{ij}}$ is the deterministic location utility (see equation 2), $c_{j}$ is the centrality measure (see equation 3 ), and centrality parameter $\theta_{s}^{\mathrm{LC}}$. This centrality parameter measures the extent to which location alternatives are evaluated in clusters.
If $\theta_{s}^{\mathrm{LC}}<0$, competition effects are present. In other words, alternatives that are close to many other alternatives are less likely to be selected than more isolated alternatives.

\subsection{Transport-based accessibility}

The quality of transport-based accessibility is measured in terms of proximity to transport infrastructure access points and with logsum accessibility measures. Proximity measures express a specific quality of transport infrastructure that is easily interpreted, such as the distance to a train station. Earlier empirical findings suggest that such measures can be significant factors in the location preferences of firms (Bok and Sanders 2005). Logsum measures are less easily interpreted, but provide the most conclusive valuation of all travel opportunities that can be reached from a location, taking into account individual preferences, available modes of transport, and variation in congestion levels, travel times, and travel costs over the course of day (Jong et al. 2007).

The distances to the nearest highway entrance ramp and the nearest train station are included as spatial attributes, re-coded into a categorical variable describing the orientation of a location vis-a-vis the transport infrastructure. An $\alpha$-location is a typical train station location: within 800 meters of a train station and not too close to a highway entrance ramp. A location within 2000 meters of a highway entrance ramp is designated as a $\gamma$-location. If a location is close to both a train station and a highway entrance ramp (within 800 meters and 2000 meters, respectively) it is designated a $\beta$-location. If a location has a considerable distance to both the nearest train station and highway onramp, it is designated a p-location. The models' location type dummies are implemented with an effect-coding scheme so the parameter for $p$-locations can be derived from the estimated parameters for $\alpha \beta \gamma$-locations. This typology resembles the policy-based accessibility categorization of locations used by the Dutch government (Schwanen et al. 2004).

The second type of accessibility measure, based on logsums, is well-founded in microeconomic theory (Jong et al. 2007). The logsums for two trip purposes are assumed to be relevant for firm location decisions: the logsum for (non-home-based) business trips and the (reflected) logsum for commuting trips. The logsum for business trips is assumed to be representative of customer and supplier accessibility; it is calculated as the sum of the trip utilities to all destination zones $d$ for all person types $p$ for all trips:

$$
A_{\text {om }}=\log \sum_{d} \sum_{p} \exp \left(\mu_{m} V_{\text {odpm }}\right)
$$


with purpose $m=$ 'business trips', $V_{o d p m}$ as the expected utility for person type $p$ to make a business trip from origin $o$ to destination $d$ and $\mu_{m}$ with the purpose-specific scale parameter.

Labor market accessibility is derived from the utility of commuting trips in the transport model from the perspective of the employer. For this reason, we analyze the commuting trips with a reflected logsum that measures the accessibility at the destination side of all commuting trips. The reflected logsum for commuting trips at firm location $d$ is specified as:

$$
A_{\mathrm{dm}}=\log \sum_{o} \sum_{p} \exp \left(\mu_{m} V_{\text {odpm }}\right)
$$

with trip purpose $m$ 'commuting' and $V_{\text {odpm }}$ as the expected utility for person type $p$ to commute from origin $o$ to destination $d$.

\subsection{Measures of agglomeration}

We account for the transport dimension in spatial externalities explicitly by computing a range band around each firm location based on travel times derived from the transport model. The level of agglomeration within each range band is measured by the level and composition of employment within the band. Analyzing the specialization or concentration of specific industries tests for the existence of Marshallian externalities. Jacobs' externalities are measured by the degree of diversity in the firm population around the firm location.

\section{Concentration}

Concentration is measured as the representation of an industry within a specified travel range around a location relative to that industry's share in the region. The measure is based on the production specialization (PS) index, and enhanced with a spatial dimension with range bands. For each location $j$, the level of agglomeration is measured in specific range bands, $R_{j b}$. We applied a range band of 7.5 minutes, as research by van Soest et al. (2006) reveals that the spatial reach and impacts of agglomeration externalities in South-Holland are limited. For location $j$, the share of the employment in sector $s$ in a range band $R_{j b}$ from $j$ is measured relative to the share of employment in that industry in the whole region. The production specialization index for location $j$ and range band $R_{j b}$ becomes:

$$
\mathrm{PS}_{\mathrm{jsb}}=\frac{E_{\mathrm{sR}_{\mathrm{jb}}} / \sum_{s} E_{\mathrm{sR}_{\mathrm{jb}}}}{\sum_{j} E_{\mathrm{sR}_{\mathrm{jb}}} / \sum_{j} \sum_{s} E_{\mathrm{sR}_{\mathrm{jb}}}}
$$

with $E_{\mathrm{sR}_{\mathrm{jb}}}$ as the employment in industry within range band $R_{j b}$

\section{Diversity}

We measured diversity of the firm population within a range band with the productivity diversity index (Paci and Usai 1999). If $S$ defines the number of industries and all industries are sorted in increasing order, then the production diversity index $P D_{j b}$ for location $j$ and range band $R_{j b}$ is defined as:

$$
\mathrm{PD}_{\mathrm{jb}}=\frac{1}{(S-1) E_{\mathrm{SR}_{\mathrm{jb}}}} \sum_{S-1}^{s=1} E_{\mathrm{sR}_{\mathrm{jb}}}
$$

where $E_{\mathrm{sR}_{\mathrm{jb}}}$ represents employment in the largest industry within range band $R_{j b}$.

\subsection{Data}

The study area for which the empirical models in this article are estimated is the Dutch province of South-Holland. It is located at the southwestern edge of the Dutch Randstad region, which has a high population density (roughly 1,190 persons $/ \mathrm{km}^{2}$ ). See Figure 1; top left. It includes the secondand third-largest cities in the Netherlands (Rotterdam and The Hague) as well as numerous medium-sized cities including Leiden, Delft, Schiedam, and Dordrecht. The longitudinal data cover the period 1988-1997, and after derivation of firm transition variables (growth, relocation), the dataset available for estimation covers the period 1990-1996. Henderson (1997) and Combes (2000) find that effects of agglomeration economies on economic growth peak after approximately five years and die out after six to seven years. Thus, the interval over which relocation was measured appears to be long enough to allow measurable differences over regions and locations to emerge.

The longitudinal firm data include the location and other attributes for all business establishments from the Firm Register South-Holland (see fragment of research area at upper right in Figure 1). These establishments can be part of firm with multiple establishments, but this information is not in the database, and more important, the location of establishments is the most relevant level of analysis in disaggregate urban studies. The longitudinal data are of interest for several reasons. First, the data covers all establishments in SouthHolland in each year of the sample period. The dataset includes annually updated information on all establishments in the region (approximately 90000). Establishments are enumerated based on information furnished by the Chamber of 
Commerce, insurance companies, and industrial-sector associations; an annual questionnaire is sent to each. The average annual response rate to the questionnaire is 96 percent. Second, the data are available at a very fine scale. Questionnaire results identify each firm's six-digit postal code (corresponding to a small area containing about 100 mailing addresses), and five-digit activity code. These features offer an advantage when testing for spatial externalities. The spatial scale at which the firm dynamics can be studied is very small, particularly when compared to counties or cities in the United States, which in some cases are defined as two or more contiguous counties. The entire area of South Holland measures $2350 \mathrm{~km}^{2}$.

In this article, we focus on five industry sectors: manufacturing, construction, transport and distribution, producer services (banking, insurance, and consultancy), and consumer services (retail and personal services). These industries are expected to have different preferences in terms of accessibility and agglomeration economies. For each year, the reported firm population for these sectors was around 35,000 firms. During estimation of the location choice models, we filtered out very small firms (one or two employees) to avoid disturbances from 'empty' (purely administrative) firms.

The firm data used in this research include the following attributes for each firm: industry (aggregated into broad sectors), size (in full-time employment units), age (number of years in operation), location (six-digit postal code), change in size compared to previous years, and dummy variables for firm demographic events (founding, relocation, closure). The spatial detail of firm locations allows a detailed analysis of spatial attributes of each location. Firm growth is expressed as the change in firm size relative to absolute size. The age of the firm is included in the estimations by a 'youngness' attribute, defined as 'youngness' $=1$ /age.

The measures of proximity to transport infrastructure access points are calculated from the location of each firm (postal code) and a geographic information systems (GIS) analysis. In this analysis, the distance is computed from the establishment to the nearest highway entrance ramp and the nearest train station.

The logsum accessibility attributes (Figure 1, bottom left) and the travel time between zones in the study area are derived from the National Modeling System (NMS), the national transport model for the Netherlands (Hague Consulting Group 2000). The model, developed by the Transport Research Centre, has been applied in a backcasting study that made travel times and logsums available back to 1985. The NTM is based on disaggregate discrete choice models, and provides the logsums used in equations 5 and 6 . The congested travel time matrices are calculated during the peak hour, and are used to determine range-band $\mathrm{Rj} b$ for each zone. The attributes for diversification or specialization are derived from the firm population that falls within a range band around each location, following equations 7 and 8 . The result for specialization of firms in business services is visualized in the bottom right portion of Figure 1.

The small size of South-Holland is helpful in controlling for location-specific factors that might affect growth and location choice (van Soest et al. 2006). In fact, many of the variables enumerated in prior studies (Ellison and Glaeser 1999; Henderson 1997; Henderson et al. 1995; Kim 1999) as potentially important location-specific factors either are roughly constant between locations in South-Holland, or can be controlled for to some extent. Cultural differences between locations in South-Holland are negligible. Variations in taxes, environmental amenities (such as climate), and environmental regulations between locations are quite small. Differences in prices of non-land inputs exhibit little variation across the province. Prices for energy inputs vary by sector, but are the same throughout the province within a sector. Wages also vary by sector, but the variation is small within sectors. The province is small enough that workers can live in one postal code and commute to work in almost any other (as well as to areas in other provinces) using either public or private transportation modes, and in fact they do. Thus, wage rates within a sector are uniform (Broersma and van Dijk 2002) and there is no need to control for labor force characteristics such as level of education, proportion of workers with particular skills, or proportion of workers who are union members.

\section{Results}

Following van Oort (2004), who identifies distinctive firm location behaviors over broadly defined economic sectors, our analysis distinguishes between firms in manufacturing, construction, transport and distribution, producer services and consumer services.

\subsection{Relocation probability}

The binary regression models for relocation probabilities include firm attributes and accessibility and agglomeration attributes (see equation 1). The life cycle of firms is captured in the attributes firm size, age, and (employment) growth. The firm's sector is included with a dummy variable. These variables relate to the first four hypotheses presented in Section 2. 
Figure 1: Clockwise from top left: the research area; detail of the firm data and proximity to transport infrastructure; specialization index; logsum for commuting trips.
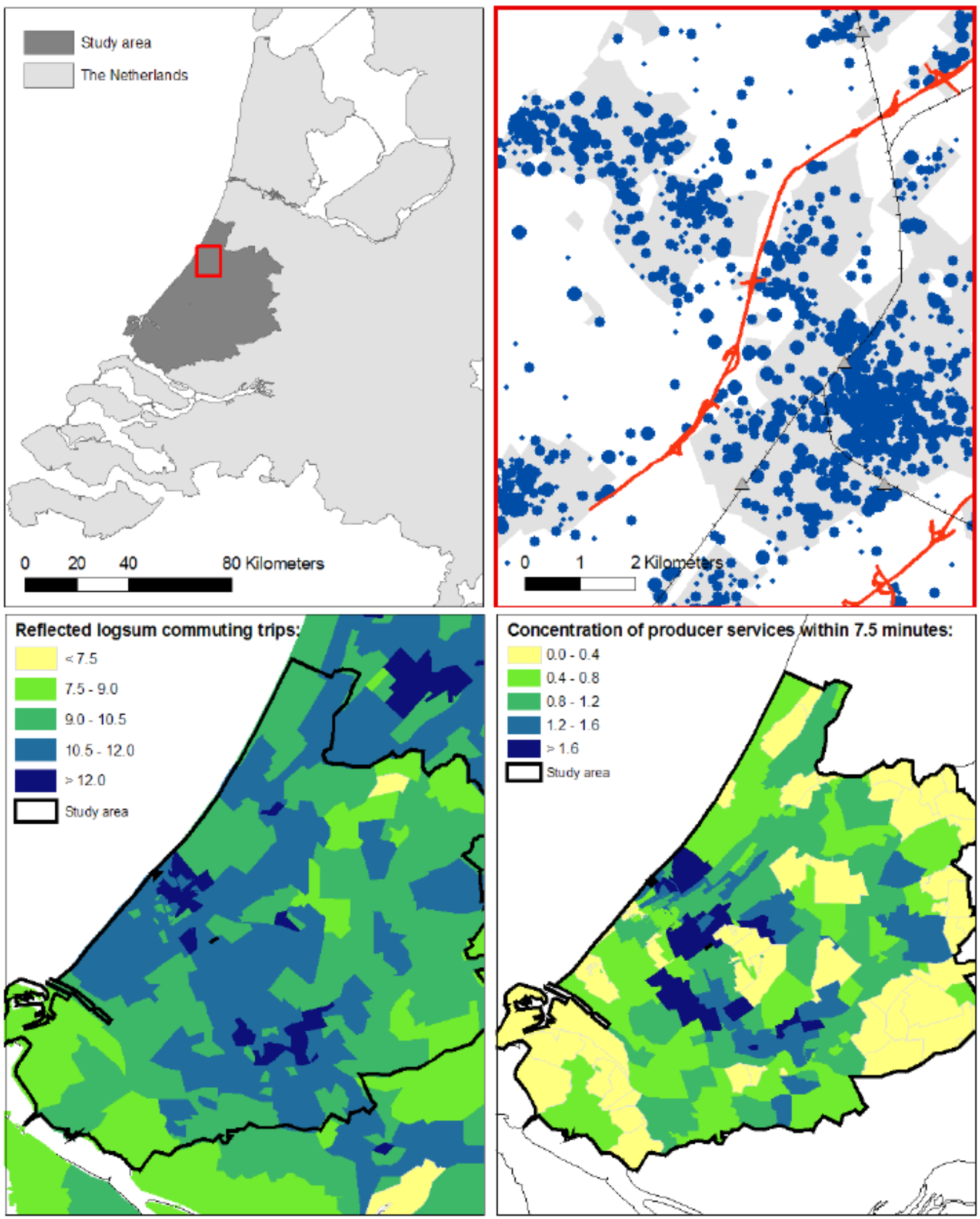
Table 2: Composition of firm population-observations in the estimation sets.

\begin{tabular}{lrrrrrrrr}
\hline & 1990 & 1991 & 1992 & 1993 & 1994 & 1995 & 1996 & Total \\
\hline Firm population by sector from 1990-1996 & & & & & & & & \\
Manufacturing & 5837 & 5859 & 5842 & 5810 & 5810 & 5567 & 5461 & 40186 \\
Construction & 5979 & 5965 & 6010 & 6072 & 6030 & 5900 & 5884 & 41840 \\
Transport, Warehousing and Communication & 4528 & 4534 & 4542 & 4589 & 4647 & 4579 & 4576 & 31995 \\
Producer services & 10711 & 11058 & 11598 & 12206 & 12683 & 12995 & 13310 & 84561 \\
Consumer Services & 7137 & 7087 & 7173 & 7350 & 7313 & 7456 & 7619 & 51135 \\
\cline { 2 - 7 } Total & 34192 & 34503 & 35165 & 36027 & 36483 & 36497 & 36850 & 249717 \\
\hline & & & & & & & & \\
Observed relocations (firms > 3 employees) & 119 & 95 & 111 & 95 & 106 & 106 & 121 & 753 \\
Manufacturing & 153 & 112 & 149 & 141 & 144 & 165 & 169 & 1033 \\
Construction & 143 & 122 & 131 & 85 & 142 & 113 & 161 & 897 \\
Transport, Warehousing and Communication & 304 & 249 & 265 & 243 & 325 & 286 & 319 & 1991 \\
Producer services & 58 & 59 & 66 & 58 & 62 & 73 & 66 & 442 \\
Consumer Services & 964 & 816 & 905 & 796 & 990 & 930 & 1069 & 6470 \\
Total & & & & & & &
\end{tabular}

Table 3 presents the estimated $\beta$ coefficients with their corresponding standard errors for three different model specifications. A higher value of $\beta$ means a higher probability of relocating. The significance level of the estimated parameters are indicated with ${ }^{* *}(1 \%)$ or ${ }^{*}(5 \%)$. Model MP-1 describes a base set-up, including the agglomeration attributes of specialization and diversity. Next, model MP-2 includes the youngness (age) attribute, defined as 1/age. Model MP-3 includes the urbanization attribute to determine the effect of the inclusion of this attribute on the other estimated parameters.

The estimated parameters show that relocation probabilities are mainly influenced by firm attributes. The size and growth rate parameters are negatively significant. The negative parameter for the log of firm size indicates that larger firms are less likely to relocate (Brouwer et al. 2004; Carroll and Hannan 2000; Maoh and Kanaroglou 2007). This confirms our first hypothesis. The same holds for age: the positive parameters for the youngness attribute in models MP-2 and MP-3 indicate that young firms are more likely to relocate. The decrease in significance of the estimated parameter for firm size in model MP- 2 compared to MP- 1 is caused by the correlation between age and size. However, the sign of the estimated parameter remains negative, indicating that larger firms are less likely to move and confirming our second hypothesis. Furthermore, firms with high growth rates are more likely to relocate (Carroll and Hannan 2000; Louw 1996; Maoh and Kanaroglou 2007; Pellenbarg et al. 2002). The positive parameter for absolute growth rates in model MP-1 (0.432) indicates a higher relocation probability for expanding or contracting firms. Apparently, firm growth (or contraction) can cause a mismatch with the available space at the current location, resulting in a decision to relocate. This confirms our third hypothesis.

Relocation probability varies across industries as well, as suggested by our fourth hypothesis. Next to firms in producer services (hypothesized), firms involved in transport activities are the most mobile with the largest estimated parameters (of 0.656 and 0.673 in MP- 3 ). The firms in consumer services (the reference category) make up the least mobile industry. This sector consists of retail and non-profit organizations that have fewer reasons to relocate because they are attached to local service areas.

The propensity to relocate can be linked to agglomeration externalities and infrastructure proximity as well. The positive parameters for diversity in the models indicate that firms in diverse locations are more likely to relocate. Similar evidence is found in Holl (2004b) for the relocation of manufacturing firms in Portugal. The estimated parameters for Model MP-3 show that the inclusion of the urbanization attribute affects the diversity parameter, indicating correlation. The inclusion of the urbanization attribute leads to a decrease in the value of the diversity parameter from 0.430 in MP- 2 to 0.100 in MP3 . The estimated parameters for $\alpha \beta \gamma$-locations reveal a modest influence of infrastructure proximity on the propensity of firms to relocate. Firms near motorway onramps ( $\gamma$-locations) are less likely to relocate. This can be interpreted as evidence 
Table 3: Estimated parameters relocation probability.

\begin{tabular}{|c|c|c|c|c|c|c|}
\hline & \multicolumn{2}{|c|}{ MP-I } & \multicolumn{2}{|c|}{ MP-II } & \multicolumn{2}{|c|}{ MP-III } \\
\hline & $\beta$ & S.E. & $\beta$ & S.E. & $\beta$ & S.E. \\
\hline Constant & -3.907 & $0.053^{* *}$ & -3.997 & $0.053^{* *}$ & -5.24 & $0.131^{* *}$ \\
\hline \multicolumn{7}{|l|}{ Individual firm attributes } \\
\hline Log of size & -0.023 & $0.008^{* *}$ & 0.01 & 0.008 & 0.004 & 0.008 \\
\hline Growth rate & 0.432 & $0.035^{* *}$ & 0.386 & $0.035^{* *}$ & 0.392 & $0.036^{* *}$ \\
\hline $1 /$ age & & & 0.797 & $0.037^{* *}$ & 0.775 & $0.038^{* *}$ \\
\hline \multicolumn{7}{|l|}{ Industry sector } \\
\hline Manufacturing & 0.221 & $0.039^{* *}$ & 0.207 & $0.039^{* *}$ & 0.211 & $0.04^{* *}$ \\
\hline Construction & 0.531 & $0.036^{* *}$ & 0.531 & $0.036^{* *}$ & 0.551 & $0.037^{* *}$ \\
\hline Transport, Warehousing and Communication & 0.697 & $0.037^{* *}$ & 0.672 & $0.037^{* *}$ & 0.673 & $0.038^{* *}$ \\
\hline Producer services & 0.741 & $0.031^{* *}$ & 0.663 & $0.031^{* *}$ & 0.656 & $0.032^{* *}$ \\
\hline Consumer Services & - & & - & & - & \\
\hline \multicolumn{7}{|l|}{ Accessibility attributes } \\
\hline$\alpha$-location; near train station & 0.076 & $0.031^{*}$ & 0.083 & $0.028^{* *}$ & 0.079 & $0.028^{* *}$ \\
\hline$\beta$-location; near train station and highway onramp & 0.029 & 0.022 & 0.015 & 0.021 & 0.01 & 0.022 \\
\hline$\gamma$-location; near highway onramp & -0.068 & $0.02^{* *}$ & -0.07 & $0.018^{* *}$ & -0.063 & $0.018^{* *}$ \\
\hline p-location; neither & -0.036 & & -0.028 & & -0.026 & \\
\hline \multicolumn{7}{|l|}{ Urbanization economies } \\
\hline Logsum business and commuting trips & & & & & 0.075 & $0.007^{* *}$ \\
\hline \multicolumn{7}{|l|}{ Agglomeration attributes } \\
\hline Diversity within $<7,5 \mathrm{~min}$. & 0.492 & $0.067^{* *}$ & 0.43 & $0.067^{* *}$ & 0.1 & 0.075 \\
\hline Specialization within $<7,5 \mathrm{~min}$. & 0.057 & $0.014^{* *}$ & 0.041 & $0.014^{* *}$ & 0.032 & $0.015^{*}$ \\
\hline Number of observations & 249717 & & 249717 & & 249717 & \\
\hline Cox and Snell & 0.004 & & 0.006 & & 0.006 & \\
\hline Nagelkerke & 0.014 & & 0.019 & & 0.021 & \\
\hline
\end{tabular}

${ }^{* *}=$ significant at the 0.99 level $;{ }^{*}=$ significant at the 0.95 level

for higher satisfaction among firms at such locations. The estimated parameter for $\alpha$-locations shows that firms near train stations are more likely to relocate (probably towards locations more accessible by car).

\subsection{Firm relocation choices}

Table 4 presents the estimated location choice parameters for the producer services and the consumer services sectors. Table 5 presents the results for manufacturing and construction sectors. Finally, Table 6 presents the results for the transport and distribution sector. To avoid biases from small, inactive firms, the location choice models are estimated on all observed relocations of firms that have more than two employees. Some observations are excluded from the analysis because address information for the the new or original locations was incomplete. The dataset covers a total of 5,116 relocated firms.
For each sector, we estimate four models with different combinations of accessibility and agglomeration parameters. Model I is a base set up for the model that includes the regular attributes for accessibility and agglomeration. Models II-IV each test the effect of adding a specific interaction term with an individual firm attribute into the analysis. Model II tests whether growing firms have a stronger preference for specialized locations; Model III tests the influence of age (youngness) on specialization; and Model IV tests the influence of age on preferences for locations with high diversity. We discuss the estimation results in the light of Hypotheses 5-10.

Hypotheses 5 and 6: Relocating firms prefer specialized locations

The estimation results provide strong evidence that relocating firms in the producer services sector prefer specialized loca- 
tions where they are near other firms in the same sector. The same is true of firms in the manufacturing, construction, and transport sectors.

This result can be interpreted as evidence for the existence of Marshallian externalities. The specialization parameters for general services are negative but not significant. The growth/specialization interaction term in Model II is only significant for the construction sector (at 99\% conf. level), and the producer services sector (at $95 \%$ conf. level). The growth/specialization interaction terms were insignificant for the other sectors. These results do not constitute strong evidence that growing firms prefer specialized locations. Instead, the fact that the estimated parameters for the youngness/specialization interaction term in Model III are positive and significant for producer services, manufacturing and transport suggests that relocating young firms in these sectors attribute a higher location utility to alternatives in specialized locations. Evidence for the existence of a locational preference for diverse locations is not found for firm relocations. Few of the estimated parameters are significant in that respect, with the exception of firms in the transport sector. As the previous section showed that fast-growing (maturing) young and small firms have a greater propensity to relocate from diversified locations, our results in this section suggest that maturing firms move towards more specialized locations and cities. This is in line with the interpretation put forward by Duranton and Puga (2001) and Neffke (2009), which holds that local sectoral diversity is a dominant characteristic of agglomeration externalities during the early stages of firms' or sectors' life cycles ('nursery cities'), while local specialization characterizes the clustering of more mature firms and industries. Although more longitudinal research is needed, this implies that maturing firms ideally move from diversified breeding places to specialized clusters of related firms. ${ }^{8}$

\section{Hypothesis 7: Relocating firms prefer locations that contain larger urbanization economies}

This hypothesis is tested with the estimated parameters for the logsum for commuting and business trips. The estimated parameters reveal a significant and positive preference for urbanization economies in the producer services, consumer services, and transport sectors (not for industrial firms). The logsums measure how well a location can be accessed by commuters or business travelers given the available travel options in the

\footnotetext{
${ }^{8}$ To test this theory properly would require more longitudinal information on urban externalities and their interaction with age and size variety of firms than has been used in our analysis.
}

transport model, including private automobiles (under congested traffic conditions) and public transport. So, the significant parameters show that the firms in these sectors prefer locations with good travel options for business travelers and commuters, a finding that supports the hypothesis that urbanization economies are important for firm relocation. Producer services are dependent on a relatively highly skilled labor force, so good accessibility across all modes of transport is an advantage for this sector. Consumer services firms often provide public services that need to be accessible by as much people as possible, so these firms need to be accessible by car and public transport as well. Good accessibility to other firms is an advantage (in terms of efficiency and transport cost reduction) for firms in the transport and distribution sector, considering their role in the logistics of industries. We found no significant results for the construction and manufacturing sectors; firms in these sectors require more space for their activities, and presumably strike a different balance between accessibility and land rent. Previous research on the location dynamics of firms in the Netherlands shows that these sectors are likely to prefer less expensive locations and to accept a lower level of accessibility (van Oort 2004).

\section{Hypotheses 8 and 9: Significant and industry-specific preferences for infrastructure proximity}

The estimated parameters for the four location type dummies reveal a significant (Hypothesis 8) and industry-specific (Hypothesis 9) preference for infrastructure location types. Firms in the business services sector exhibit a significant preference for locations that are close to highway entrance ramps and train stations ( $\beta$-locations). Proximity to train stations provides good accessibility by public transport for the commuters in this sector. Highway proximity allows convenient access for business trips to customers or for commuting. The estimated proximity parameters were not significant at the $95 \%$ confidence level in the other industry sectors (nor for firms in the distribution sector, as anticipated in Hypothesis 9). This is attributable, in part, to the smaller number of observations in these sectors, but might also be a product of the simplicity and distance bias included in the measure (a single threshold value based on distance). However, in terms of choice behavior, the simplicity of the measure is also an advantage because the proximity measure is directly observed by the decision makers: is a location close to a train station or not? Hence, we will discuss some parameters that exhibit a lower significance but that do indicate a plausible preference. We stress that these results were not statistically significant; however, they do appear relevant to us. For instance, the manufacturing and con- 
struction sectors have positive parameters for $\gamma$-locations with a relatively small standard error $(t>1.2$ for manufacturing or $t>1.8$ for construction). Proximity to highway infrastructure is relevant because firms in these sectors have relatively large input and output flows. The $\rho$-parameter (no train station or highway entrance nearby) is computed as the negative of the sum of $\alpha \beta \gamma$-parameters (effect coding). Although most $\alpha \beta \gamma$ parameters are not significant, the resulting parameter for $p$ locations is negative, which is plausible considering the lack of proximity to any infrastructure. This explains the value of the distance-based location attributes in the choice behavior of firms.

\section{Hypothesis 10: Preference for limited migration distance ${ }^{9}$}

Firms in all sectors attach a significant disutility to relocation distance: the estimated parameters for relocation distance are negative and significant in all model specifications. Firms prefer locations in the environs of the original location. Similar results are reported in Pellenbarg et al. (2002) and Maoh and Kanaroglou (2007) for SMEs in Canada. This result confirms the existence of keep-factors: relocating firms strive to maintain their existing spatial relations with employees, customers and suppliers. These relationships are less strongly affected if the new location is closer to the current location, so firms are inclined to relocate over shorter distances. Firms in the consumer services sector attach the highest disutility to relocation distance. This can be expected, as this sector relies mostly on local networks and the presence of customers.

\footnotetext{
${ }^{9}$ The spatial competition between clustered alternatives can be observed and measured with the centrality parameter $\theta$. The centrality measure is used as a proxy for the spatial competition between location alternatives, in a similar way as a path-size logit model is used for overlapping routes in route choice models. If the estimated parameter $\theta<0$, competition effects are present and alternatives will compete with others nearby. If $\theta>0$, spatial alternatives that are clustered are likely to be selected over more isolated alternatives. The estimated coefficients for the centrality parameter $\theta$ are significant and negative for all sectors. This shows that choice alternatives that are spatially clustered have a smaller choice probability. This is in line with empirical findings produced by other competing destination models in the literature (Pellegrini and Fotheringham 2002). Please note that the centrality parameter refers to the evaluation process of grouped choice alternatives, and not to a locational quality. Grouped alternatives have similar location attributes and are therefore more likely to be substitutes for each other (a competition effect). As a result, individual alternatives within the cluster have smaller choice probabilities. The significant influence of spatial competition on location choices implies that the location choice model must account for spatial competition between alternatives. This research used an observable proxy measure in the deterministic part of the location utility.
}

\section{Conclusions}

Our analysis of firm relocation in a spatially disaggregated urban environment reveals that a firm's relocation probability is predominantly determined by attributes of the firm itself. Larger and older firms are less likely to relocate, and firms with relatively high growth rates are more likely to relocate. Relocation probability varies across industry sectors (with producer service and transportation firms having the greatest propensity to relocate), but the influence of accessibility appears to be limited compared to firm-level attributes. Agglomeration indicators have a relatively large effect. Relocating firms have a significant preference for locations in close proximity to their original locations. We interpret this as evidence for the existence of keep-factors: a relocating firm strives to maintain their existing spatial networks of customers, suppliers, and labor. This keep-factor effect is naturally strongest for firms in the consumer services sector, since they are dependent on their local customers. The preference for locations with ready access to highways and/or train stations proves to be significant for relocating firms, but its effect differs across sectors. Firms in the producer services, consumer services, and transport sectors are characterized by a preference for locations with good accessibility to labor markets (urbanization economies). Marshallian externalities appear significant in the estimation results for the producer services, manufacturing, construction, and transport sectors. Relocating firms in these sectors prefer specialized locations with significant numbers of firms from their own industries. We interpret this as evidence for the existence of Marshallian externalities, consistent with the findings of Duranton and Puga (2001).

Similar to the work of Duranton and Puga (2001) and Neffke (2009), we interpret the results within a framework that considers the changing importance of agglomeration externalities over the life cycle of firms and industry sectors. Our analyses showed that young, small firms that are growing rapidly (maturing) have a higher propensity to relocate from diversified locations towards more specialized locations and cities, suggesting that sectoral diversity is a dominant agglomeration externality early in the life cycles of firms or sectors (cf. the concept of 'nursery cities'). Although more longitudinal research is needed, this finding implies that maturing firms, ideally, move from diversified breeding grounds to areas with specialized clusters of related firms. This theory might be able to explain the simultaneous importance of various agglomeration externalities for growing and relocating firms in the literature (Groot et al. 2009). A changing importance of agglomeration externalities along the life cycle of a firm, forces ur- 
Table 4: Estimated parameters for relocated firms in business services and general services.

\begin{tabular}{|c|c|c|c|c|c|c|c|c|}
\hline \multirow[t]{2}{*}{ BUSINESS SERVICES: } & \multicolumn{2}{|c|}{ Model I } & \multicolumn{2}{|c|}{ Model II } & \multicolumn{2}{|c|}{ Model III } & \multicolumn{2}{|c|}{ Model IV } \\
\hline & $\beta$ & S.E. & $\beta$ & S.E. & $\beta$ & S.E. & $\beta$ & S.E. \\
\hline \multicolumn{9}{|l|}{ Migration attribute } \\
\hline Distance to original loc. $\left[\mathrm{km}^{1} /^{2}\right]$ & -1.88 & $0.04^{* *}$ & -1.88 & $0.04^{* *}$ & -1.88 & $0.04^{* *}$ & -1.88 & $0.04^{* *}$ \\
\hline \multicolumn{9}{|l|}{ Infrastructure proximity } \\
\hline$\alpha$-location; near train station $[-]$ & -0.04 & 0.11 & -0.08 & 0.11 & -0.06 & 0.11 & -0.04 & 0.11 \\
\hline $\begin{array}{l}\text { B-location; near train station and highway on- } \\
\text { ramp [-] }\end{array}$ & 0.24 & $0.07^{* *}$ & 0.25 & $0.07^{* *}$ & 0.25 & $0.07^{* *}$ & 0.24 & $0.07^{* *}$ \\
\hline$\gamma$-location; near highway onramp [-] & -0.02 & 0.06 & 0.04 & 0.06 & 0.01 & 0.06 & -0.02 & 0.06 \\
\hline p-location; neither [-] & -0.18 & & -0.21 & & -0.2 & & -0.19 & \\
\hline \multicolumn{9}{|l|}{ Urbanization economies } \\
\hline Logsum business/commute trips [-] & 0.202 & $0.03^{* *}$ & 0.227 & $0.03^{* *}$ & 0.215 & $0.03^{* *}$ & 0.202 & $0.033^{* *}$ \\
\hline \multicolumn{9}{|l|}{ Diversity attributes } \\
\hline Diversity $\mathrm{Rb}<7,5$ min. $[-]$ & 0.11 & 0.24 & -0.07 & 0.24 & 0.03 & 0.24 & & \\
\hline Diversity x Age [-] & & & & & & & 1.79 & 1.15 \\
\hline \multicolumn{9}{|l|}{ Specialization attributes } \\
\hline Specialization $\mathrm{Rb}<7,5$ min. [-] & 0.45 & $0.07^{* *}$ & & & & & 0.46 & $0.07^{* *}$ \\
\hline Specialization x Age [-] & & & & & 1.73 & $0.34^{* *}$ & & \\
\hline Specialization x Growth [-] & & & 0.35 & $0.17^{*}$ & & & & \\
\hline \multicolumn{9}{|l|}{ Centrality parameter } \\
\hline$\theta[-]$ & -1.38 & $0.15^{* *}$ & -1.19 & $0.15^{* *}$ & -1.28 & $0.15^{* *}$ & -1.41 & $0.14^{* *}$ \\
\hline Number of observations & 1991 & & 1991 & & 1991 & & 1991 & \\
\hline Init log-likelihood & -5965 & & -5965 & & -5965 & & -5965 & \\
\hline Final log-likelihood & -3588 & & -3603 & & -3594 & & -3587 & \\
\hline Rho-square & 0.398 & & 0.396 & & 0.397 & & 0.399 & \\
\hline \multirow[t]{2}{*}{ GENERAL SERVICES: } & \multicolumn{2}{|c|}{ Model I } & \multicolumn{2}{|c|}{ Model II } & \multicolumn{2}{|c|}{ Model III } & \multicolumn{2}{|c|}{ Model IV } \\
\hline & $\beta$ & S.E. & $\beta$ & S.E. & $\beta$ & S.E. & $\beta$ & S.E. \\
\hline Distance to original loc. $\left[\mathrm{km}^{1}{ }^{2}\right]$ & -2.24 & $0.1^{* *}$ & -2.23 & $0.1^{* *}$ & -2.22 & $0.1^{* *}$ & -2.24 & $0.1^{* *}$ \\
\hline \multicolumn{9}{|l|}{ Infrastructure proximity } \\
\hline$\alpha$-location; near train station $[-]$ & 0.2 & 0.29 & 0.21 & 0.29 & 0.21 & 0.29 & 0.19 & 0.29 \\
\hline $\begin{array}{l}\text { B-location; near train station and highway on- } \\
\text { ramp [-] }\end{array}$ & 0.15 & 0.19 & 0.17 & 0.19 & 0.18 & 0.19 & 0.16 & 0.19 \\
\hline$\gamma$-location; near highway onramp [-] & 0.09 & 0.14 & 0.09 & 0.14 & 0.1 & 0.14 & 0.09 & 0.14 \\
\hline p-location; neither [-] & -0.44 & & -0.48 & & -0.5 & & -0.44 & \\
\hline \multicolumn{9}{|l|}{ Urbanization economies } \\
\hline $\begin{array}{l}\text { Logsum business/commute trips [-] } \\
\text { Diversity attributes }\end{array}$ & \multicolumn{7}{|c|}{ Diversity attributes } & $0.082^{*}$ \\
\hline Diversity $\mathrm{Rb}<7.5 \mathrm{~min} .[-]$ & -0.31 & 0.55 & -0.37 & 0.55 & -0.38 & 0.55 & & \\
\hline Diversity x Age [-] & & & & & & & 0.16 & 3.25 \\
\hline \multicolumn{9}{|l|}{ Specialization attributes } \\
\hline Specialization $\mathrm{Rb}<7.5$ min. [-] & -0.18 & 0.17 & & & & & -0.19 & 0.17 \\
\hline Specialization x Age [-] & & & & & 1.21 & 0.81 & & \\
\hline Specialization $x$ Growth [-] & & & 0.13 & 0.44 & & & & \\
\hline $\begin{array}{l}\text { Centrality parameter } \\
\theta[-]\end{array}$ & -0.78 & $0.35^{*}$ & -0.88 & $0.34^{* *}$ & -0.93 & $0.35^{* *}$ & -0.84 & $0.33^{*}$ \\
\hline Number of observations & 442 & & 442 & & 442 & & 442 & \\
\hline Init log-likelihood & -1324 & & -1324 & & -1324 & & -1324 & \\
\hline Final log-likelihood & -697 & & -697 & & -696 & & -697 & \\
\hline Rho-square & 0.474 & & 0.474 & & 0.474 & & 0.474 & \\
\hline
\end{tabular}

${ }^{* *}=$ significant at the 0.99 level $;{ }^{*}=$ significant at the 0.95 level 
Table 5: Estimated parameters for relocating firms in manufacturing and construction sectors.

\begin{tabular}{|c|c|c|c|c|c|c|c|c|}
\hline \multirow[t]{2}{*}{ MANUFACTURING: } & \multicolumn{2}{|c|}{ Model I } & \multicolumn{2}{|c|}{ Model II } & \multicolumn{2}{|c|}{ Model III } & \multicolumn{2}{|c|}{ Model IV } \\
\hline & $\beta$ & S.E. & $\beta$ & S.E. & $\beta$ & S.E. & $\beta$ & S.E. \\
\hline \multicolumn{9}{|l|}{ Migration attribute } \\
\hline Distance to original loc. [km 1/2] & -1.76 & $0.06^{* *}$ & -1.77 & $0.06^{* *}$ & -1.76 & $0.06^{* *}$ & -1.76 & $0.06^{* *}$ \\
\hline \multicolumn{9}{|l|}{ Infrastructure proximity } \\
\hline$\alpha$-location; near train station $[-]$ & 0.14 & 0.21 & 0.1 & 0.21 & 0.12 & 0.21 & 0.15 & 0.21 \\
\hline $\begin{array}{l}\text { B-location; near train station and highway on- } \\
\text { ramp [-] }\end{array}$ & -0.18 & 0.16 & -0.21 & 0.16 & -0.21 & 0.16 & -0.18 & 0.16 \\
\hline$\gamma$-location; near highway onramp [-] & 0.12 & 0.1 & 0.16 & 0.1 & 0.15 & 0.1 & 0.12 & 0.1 \\
\hline p-location; neither [-] & -0.09 & & $-0.05-$ & -0.06 & -0.09 & & & \\
\hline \multicolumn{9}{|l|}{ Urbanization economies } \\
\hline Logsum business and commuting trips [-] & 0.049 & 0.053 & 0.033 & 0.052 & 0.037 & 0.052 & 0.049 & 0.053 \\
\hline \multicolumn{9}{|l|}{ Diversity attributes } \\
\hline Diversity $\mathrm{Rb}<7.5$ min. [-] & 0.09 & 0.36 & -0.63 & 0.33 & -0.4 & 0.34 & & \\
\hline Diversity x Age [-] & & & -0.94 & 2.1 & & 0.21 & 0.94 & 2.1 \\
\hline \multicolumn{9}{|l|}{ Specialization attributes } \\
\hline Specialization $\mathrm{Rb}<7.5$ min. [-] & 0.55 & $0.09^{* *}$ & & & & & 0.54 & $0.09^{* *}$ \\
\hline Specialization $\mathrm{x}$ Age $[-]$ & & & & & 1.45 & $0.45^{* *}$ & & \\
\hline Specialization x Growth [-] & & & 0.08 & 0.21 & & & & \\
\hline \multicolumn{9}{|l|}{ Centrality parameter } \\
\hline$\theta[-]$ & -0.94 & $0.3^{* *}$ & -0.92 & $0.3^{* *}$ & -0.92 & $0.3^{* *}$ & -0.91 & $0.29^{* *}$ \\
\hline Number of observations & 753 & & 753 & & 753 & & 753 & \\
\hline Init log-likelihood & -2256 & & -2256 & & -2256 & & -2256 & \\
\hline Final log-likelihood & -1305 & & -1324 & & -1319 & & -1305 & \\
\hline Rho-square & 0.422 & & 0.413 & & 0.415 & & 0.422 & \\
\hline \multirow[t]{2}{*}{ CONSTRUCTION: } & \multicolumn{2}{|c|}{ Model I } & \multicolumn{2}{|c|}{ Model II } & \multicolumn{2}{|c|}{ Model III } & \multicolumn{2}{|c|}{ Model IV } \\
\hline & $\beta$ & S.E. & $\beta$ & S.E. & $\beta$ & S.E. & $\beta$ & S.E. \\
\hline \multicolumn{9}{|l|}{ Migration attribute } \\
\hline Distance to original loc. [km 1/2] & -1.93 & $0.06^{* *}$ & -1.93 & $0.06^{* *}$ & -1.93 & $0.06^{* *}$ & -1.93 & $0.06^{* *}$ \\
\hline \multicolumn{9}{|l|}{ Infrastructure proximity } \\
\hline$\alpha$-location; near train station $[-]$ & -0.07 & 0.2 & -0.06 & 0.2 & -0.07 & 0.2 & -0.07 & 0.2 \\
\hline $\begin{array}{l}\beta \text {-location; near train station and highway on- } \\
\text { ramp [-] }\end{array}$ & 0.12 & 0.14 & 0.11 & 0.14 & 0.11 & 0.14 & 0.12 & 0.14 \\
\hline$\gamma$-location; near highway onramp [-] & 0.16 & 0.09 & 0.17 & 0.09 & 0.17 & 0.09 & 0.16 & 0.09 \\
\hline p-location; neither [-] & $-0.21-$ & -0.22 & & -0.21 & & -0.21 & & \\
\hline \multicolumn{9}{|l|}{ Urbanization economies } \\
\hline Logsum business and commuting trips [-] & 0.007 & 0.045 & -0.003 & 0.045 & -0.006 & 0.045 & 0.006 & 0.045 \\
\hline \multicolumn{9}{|l|}{ Diversity attributes } \\
\hline Diversity $\mathrm{Rb}<7.5 \mathrm{~min} .[-]$ & 0.09 & 0.32 & 0.04 & 0.32 & 0.03 & 0.32 & & \\
\hline Diversity x Age [-] & 0.03 & 2.16 & & & & & & \\
\hline \multicolumn{9}{|l|}{ Specialization attributes } \\
\hline Specialization $\mathrm{Rb}<7.5 \mathrm{~min} .[-]$ & 0.21 & $0.08^{* *}$ & & & & & 0.21 & $0.08^{* *}$ \\
\hline Specialization x Age [-] & 0.58 & 0.7 & & & & & & \\
\hline Specialization x Growth [-] & 0.52 & $0.17^{* *}$ & & & & & & \\
\hline $\begin{array}{l}\text { Centrality parameter } \\
\theta[-]\end{array}$ & -1.3 & $0.29^{* *}$ & -1.37 & $0.29^{* *}$ & -1.36 & $0.29^{* *}$ & -1.28 & $0.29^{* *}$ \\
\hline Number of observations & 1033 & & 1033 & & 1033 & & 1033 & \\
\hline Init log-likelihood & -3095 & & -3095 & & -3095 & & -3095 & \\
\hline Final log-likelihood & -1694 & & -1695 & & -1697 & & -1694 & \\
\hline Rho-square & 0.453 & & 0.452 & & 0.452 & & 0.453 & \\
\hline
\end{tabular}

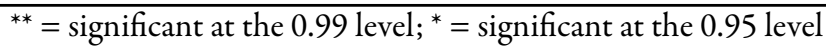


Table 6: Estimated parameters for relocated firms in transport and distribution.

\begin{tabular}{|c|c|c|c|c|c|c|c|c|}
\hline \multirow[t]{2}{*}{ TRANSPORT AND DISTRIBUTION: } & \multicolumn{2}{|c|}{ Model I } & \multicolumn{2}{|c|}{ Model II } & \multicolumn{2}{|c|}{ Model III } & \multicolumn{2}{|c|}{ Model IV } \\
\hline & $\beta$ & S.E. & $\beta$ & S.E. & $\beta$ & S.E. & $\beta$ & S.E. \\
\hline \multicolumn{9}{|l|}{ Migration attribute } \\
\hline Distance to original loc. [km1/2 ] & -1.62 & $0.06^{* *}$ & -1.65 & $0.06^{* *}$ & -1.64 & $0.06^{* *}$ & -1.62 & $0.06^{* *}$ \\
\hline \multicolumn{9}{|l|}{ Infrastructure proximity } \\
\hline$\alpha$-location; near train station $[-]$ & 0.1 & 0.19 & 0.14 & 0.19 & 0.13 & 0.19 & 0.1 & 0.19 \\
\hline $\begin{array}{l}\begin{array}{l}\text { B-location; near train } \\
\text { highwayonramp[-] }\end{array} \\
\text { station }\end{array}$ & 0.1 & 0.13 & -0.04 & 0.13 & 0 & 0.13 & 0.09 & 0.13 \\
\hline$\gamma$-location; near highway onramp [-] & 0.03 & 0.09 & 0.04 & 0.09 & 0.04 & 0.09 & 0.03 & 0.09 \\
\hline p-location; neither [-] & -0.22 & & -0.15 & & -0.16 & & -0.22 & \\
\hline \multicolumn{9}{|l|}{ Urbanization economies } \\
\hline $\begin{array}{l}\text { Logsum business and commuting trips [-] } \\
\text { Diversity attributes }\end{array}$ & \multicolumn{8}{|c|}{ Diversity attributes } \\
\hline Diversity $\mathrm{Rb}<7,5$ min. [-] & 0.32 & 0.31 & -0.92 & $0.32^{* *}$ & -0.63 & $0.31^{*}$ & & \\
\hline Diversity x Age [-] & & & & & & & 3.7 & $1.8^{*}$ \\
\hline \multicolumn{9}{|l|}{ Specialization attributes } \\
\hline Specialization $\mathrm{Rb}<7,5$ min. [-] & 0.37 & $0.04^{* *}$ & & & & & 0.37 & $0.04^{* *}$ \\
\hline Specialization x Age [-] & & & & & 1.01 & $0.22^{* *}$ & & \\
\hline Specialization $x$ Growth [-] & & & 0.11 & 0.1 & & & & \\
\hline $\begin{array}{l}\text { Centrality parameter } \\
\theta[-]\end{array}$ & -1.93 & $0.26^{* *}$ & -1.62 & $0.25^{* *}$ & -1.69 & $0.25^{* *}$ & -1.94 & $0.25^{* *}$ \\
\hline Number of observations & 897 & & 897 & & 897 & & 897 & \\
\hline Init log-likelihood & -2687 & & -2687 & & -2687 & & -2687 & \\
\hline Final log-likelihood & -1756 & & -1798 & & -1790 & & -1754 & \\
\hline Rho-square & 0.347 & & 0.331 & & 0.334 & & 0.347 & \\
\hline
\end{tabular}

${ }^{* *}=$ significant at the 0.99 level; ${ }^{*}=$ significant at the 0.95 level

ban policymakers to rethink simplified cluster (specialization) strategies aiming at nurturing young and promising firms.

In our research, firm relocation behavior is found to be affected simultaneously by urbanization economies (accessibility to population and employment), localization economies (specialization) and proximity to transport infrastructure. Localization and urbanization economies appear to be more important than proximity to transport infrastructures and sector diversity. The limited influence of the proximity attribute is likely due to the simplicity of the measure (threshold with distance) and the distance bias it includes. These results can be used to further conceptualize the interaction between accessibility, agglomeration, and firm behavior. Constraints in activity and travel patterns are an important issue in accessibility analysis; however, the accessibility measures used in this location choice analysis (logsum measures and proximity measures) do not take such constraints into account. Including accessibility measures that account for constraints on activity patterns would be a useful enhancement in future research.

One further policy recommendation, directed at the local planning arena, may be drawn from this research. The findings identified heterogeneous location preferences that can help urban planners anticipate the demand for planning schemes for industrial sites or office locations, and integrate this with transport planning schemes. An assessment of the expected demand could be made on the basis of an analysis of the composition of the existing firm population and the expected growth in different sectors. The location preferences identified in this study could help improve predictions of the types of locations that will be required to meet future demand for industrial real estate. Greater insight into the types of firms that are likely to relocate to new industrial sites could also help planners better understand which other locations are likely to face a decline in activities (and overcapacity) due to the relocation of firms.

\section{Acknowledgements}

The authors would like to thank David Levinson and three anonymous reviewers for their helpful comments to improve the manuscript. 


\section{References}

Acs, Z. J. and C. Armington. 2004. The impact of geographic differences in human capital on service firm formation rates. Journal of Urban Economics, 56(2):244-278. ISSN 00941190. doi: 10.1016/j.jue.2004.03.008.

Audretsch, D. B. and D. Dohse. 2007. Location: A neglected determinant of firm growth. Review of World Economics, 143(1):79-107. doi: 10.1007/s10290-007-0099-7.

Beugelsdijk, S. 2009. The regional environment and a firm's innovative performance: A plea for a multilevel interactionist approach. Economic Geography, 83(2):181-199. ISSN 00130095. doi: 10.1111/j.1944-8287.2007.tb00342.x.

Bok, M. D. 2009. Estimation and validation of a microscopic model for spatial economic effects of transport infrastructure. Transportation Research Part A: Policy and Practice, 43(1):44-59. doi: 10.1016/j.tra.2008.06.002. URL http://linkinghub.elsevier.com/retrieve/pii/ S0965856408001262.

Bok, M. D. and F. Sanders. 2005. Firm relocation and accessibility of locations empirical results from the Netherlands. Transportation Research Record, 1902(1):35-43. doi: 10.3141/1902-05.

Bovy, P. 2007. Modelling route choice sets in transportation networks: Principles and empirical validity. In International Symposium on Transportation and Traffic Theory. London.

Broersma, L. and J. van Dijk. 2002. Regional labour market dynamics in the Netherlands. Papers in Regional Science, 81(3):343-364. ISSN 10568190. doi: 10.1111/j.14355597.2002.tb01238.x.

Brouwer, A. E., I. Mariotti, and J. N. van Ommeren. 2004. The firm relocation decision: An empirical investigation. The Annals of Regional Science, 38(2):335-347. doi: 10.1007/s00168-004-0198-5.

Carroll, G. R. and M. T. Hannan. 2000. The demography of corporations and industries. Princeton: Princeton University Press. ISBN 9780691120157.

Cohen, W. M. and D. A. Levinthal. 1989. Innovation and learning: The two faces of $\mathrm{R} \& \mathrm{D}$. The Economic Journal, 99(397):pp. 569-596. ISSN 00130133. URL http:// www.jstor.org/stable/2233763.

Combes, P. P. 2000. Economic structure and local growth: France, 1984-1993. Journal of Urban Economics, 47:329-355. URL http://www.ingentaconnect.com/ content/ap/ue/2000/00000047/00000003/art02143.

Duranton, G. and D. Puga. 2001. Nursery cities: Urban diversity, process innovation, and the life cycle of products. The
American Economic Review, 91(5):pp. 1454-1477. ISSN 00028282 . URL http://www.jstor.org/stable/2677933.

Duranton, G. and D. Puga. 2004. Micro-foundations of urban agglomeration economies. In Handbook of Regional and Urban Economics, volume 4, pp. 2063-2117. Elsevier. URL http://ideas.repec.org/h/eee/regchp/4-48.html.

Eberts, R. and D. McMillen. 1999. Agglomeration economies and urban public infrastructure. In Handbook of Regional and Urban Economics, volume 3, pp. 1455-1495. Amsterdam: Elsevier. URL http://linkinghub.elsevier.com/ retrieve/pii/S1574008099800078.

Ellison, G. and E. L. Glaeser. 1999. The geographic concentration of industry: Does natural advantage explain agglomeration?. American Economic Review, 89(2):311-316. URL http://search.ebscohost.com/login.aspx?direct= true $\& \mathrm{db}=\mathrm{keh} \& \mathrm{AN}=1900664 \&$ site $=$ ehost-live.

Fingleton, B. and P. McCann. 2007. Sinking the iceberg? On the treatment of transport costs in new economic geography. In B. Fingleton, ed., New directions in economic geography. Cheltenham UK ;;Northampton MA: Edward Elgar. ISBN 9781845423735.

Fotheringham, A. S. 1983. A new set of spatial-interaction models: The theory of competing destinations. Environment and Planning $A, 15(1): 15-36$. ISSN 0308-518X. doi: 10.1068/a150015.

Frenken, K., F. van Oort, and T. Verburg. 2007. Related variety, unrelated variety and regional economic growth. Regional Studies, 41(5):685-697. ISSN 0034-3404. doi: 10.1080/00343400601120296.

Geurs, K. T. and G. van Wee. 2004. Accessibility evaluation of land-use and transport strategies: Review and research directions. Journal of Transport Geography, 12(2):127-140. ISSN 09666923. doi: 10.1016/j.jtrangeo.2003.10.005.

Glaeser, E. L., H. D. Kallal, J. A. Scheinkman, and A. Shleifer. 1992. Growth in cities. The Journal of Political Economy, 100(6):pp. 1126-1152. ISSN 00223808. URL http: //www.jstor.org/stable/2138829.

Grant, R. M. 1996. Toward a knowledge-based theory of the firm. Strategic Management Journal, 17:109-122. ISSN 01432095. doi: 10.2307/2486994.

Groot, H. L. D., J. Poot, and M. J. Smit. 2009. Agglomeration externalities, innovation and regional growth: Theoretical perspectives and meta-analysis. In R. Capello and P. Nijkamp, eds., Handbook of regional growth and development theories, pp. 256-281. Cheltenham: Edward Elgar. ISBN 9781847205063.

Hague Consulting Group. 2000. Het Landelijk Model Systeem versie 7.0. Technical report, Hague Consulting 
Group, The Hague.

Henderson, J. V. 1997. Externalities and industrial development. Journal of Urban Economics, 42(3):449-470. ISSN 0094-1190. doi: 10.1006/juec.1997.2036.

Henderson, J. V. 2007. Understanding knowledge spillovers. Regional Science and Urban Economics, 37(4):497-508. doi: 10.1016/j.regsciurbeco.2006.11.010.

Henderson, J. V., A. Kuncoro, and M. Turner. 1995. Industrial development in cities. The Journal of Political Economy, 103(5):1067-1090. URL http://www.jstor.org/stable/ 2138755.

Holl, A. 2004a. Manufacturing location and impacts of road transport infrastructure: Empirical evidence from Spain. Regional Science and Urban Economics, 34(3):341-363. ISSN 01660462. doi: 10.1016/S0166-0462(03)00059-0.

Holl, A. 2004b. Start-ups and relocations: Manufacturing plant location in Portugal. Papers in Regional Science, 83(4):649-668. ISSN 1056-8190. doi: 10.1007/s10110004-0218-y.

Isard, W. 1956. Location and space-economy: A general theory relating to industrial location, market areas, land use, trade, and urban structure. Cambridge, MA: MIT.

Jacobs, J. 1969. The economy of cities. New York: Vintage Books. ISBN 9780394705842.

Jong, G. D., A. Daly, M. Pieters, and T. van der Hoorn. 2007. The logsum as an evaluation measure: Review of the literature and new results. Transportation Research Part A: Policy and Practice, 41(9):874-889. ISSN 09658564. doi: 10.1016/j.tra.2006.10.002.

Jovanovic, B. 1982. Selection and the evolution of industry. Econometrica, 50(3):pp. 649-670. ISSN 00129682. URL http://www.jstor.org/stable/1912606.

Kim, S. 1999. Regions, resources, and economic geography: Sources of U.S. regional comparative advantage, 1880-1987. Regional Science and Urban Economics, 29(1):1-32. doi: 10.1016/S0166-0462(98)00010-6.

Knoben, J. 2007. A spider and the stickiness of its web: The causes and consequences of spatial firm mobility. $\mathrm{PhD}$ dissertation, Tilburg University, Tilburg.

Koo, J. 2005. Agglomeration and spillovers in a simultaneous framework. The Annals of Regional Science, 39(1):35-47. ISSN 0570-1864. doi: 10.1007/s00168-004-0210-0.

Krugman, P. 1991. Increasing returns and economic geography. Journal of Political Economy, 99(3):483-.

Leitham, S., R. W. McQuaid, and J. D. Nelson. 2000. The influence of transport on industrial location choice: A stated preference experiment. Transportation Research Part A: Policy and Practice, 34(7):515-535. doi: 10.1016/S0965-
8564(99)00030-0.

Louw, E. 1996. Kantoorgebouw en vestigingsplaats: een geografisch onderzoek naar de rol van huisvesting bij locatiebeslissingen van kantoorhoudende organtisaties. Delft, Netherlands: Delftse Universitaire Pers. ISBN 9789040713958.

Maoh, H. and P. Kanaroglou. 2007. Business establishment mobility behavior in urban areas: A microanalytical model for the City of Hamilton in Ontario, Canada. Journal of Geographical Systems, 9(3):229-252. ISSN 1435-5930. doi: 10.1007/s10109-007-0043-3.

Marshall, A. 1890. Principles of Economics. New York: Prometheus.

Martin, P., T. Mayer, and F. Mayneris. 2008. Spatial concentration and firm-level productivity in france. Technical Report CEPR Discussion Paper no. 6858, Centre for Economic Policy Research, London. URL http://www.cepr. org/pubs/dps/DP6858.asp.

Maskell, P. 2001. The firm in economic geography. Economic Geography, 77(4):329-44. doi: 10.2307/3594104.

Neffke, F. M. H. 2009. Productive Places: The influence of technological change and relatedness on agglomeration externalities. Ph.D. thesis, Utrecht University, Utrecht. URL http://igitur-archive.library.uu.nl/ dissertations/2009-0714-200508/neffke.pdf.

Neumark, D., Z. Junfu, and B. Wall. 2006. Where the jobs are: Business dynamics and employment growth. Academy of Management Perspectives, 20(4):79-94.

Ó hUallacháin, B. and M. A. Satterthwaite. 1992. Sectoral growth patterns at the metropolitan level: An evaluation of economic development incentives. Journal of Urban Economics, 31(1):25-58. ISSN 00941190. doi: 10.1016/0094-1190(92)90031-F.

Paci, R. and S. Usai. 1999. Externalities, knowledge spillovers and the spatial distribution of innovation. GeoJournal, 49(4):381-390. doi: 10.1023/A:1007192313098.

Parker, S. C. $2005 . \quad$ Explaining regional variations in entrepreneurship as multiple equilibria. Journal of Regional Science, 45:829-850.

Pellegrini, P. A. and A. S. Fotheringham. 2002. Modelling spatial choice: A review and synthesis in a migration context. Progress in Human Geography, 26(4):487-510. ISSN 14770288. doi: 10.1191/0309132502ph382ra.

Pellenbarg, P., L. van Wissen, and J. van Dijk. 2002. Firm migration. In P. McCann, ed., Industrial location economics, pp. 115-50. Cheltenham, UK: Edward Elgar.

Penrose, E. 1959. The theory of growth of the firm. Oxford: Oxford University Press. 
Raspe, O. and F. van Oort. 2008. Localized knowledge externalities and firm growth. Working paper, Netherlands Institute for Spatial Research, The Hague.

Rietveld, P. 1995. Infrastructure and spatial economic development. The Annals of Regional Science, 29(2):117-119. doi: 10.1007/BF01581801.

Rosenthal, S. S. and W. C. Strange. 2003. Geography, industrial organization, and agglomeration. Review of Economics and Statistics, 85(2):377-393. ISSN 0034-6535. doi: 10.1162/003465303765299882.

Rosenthal, S. S. and W. C. Strange. 2004. Evidence on the nature and sources of agglomeration economies. In J. V. Henderson and J.-F. Thisse, eds., Cities and Geography, volume 4 of Handbook of Regional and Urban Economics, pp. 2119-2171. Elsevier.

Schwanen, T., M. Dijst, and F. Dieleman. 2004. Policies for urban form and their impact on travel: The Netherlands experience. Urban Studies, 41(3):579-603. ISSN 0042-0980. doi: 10.1080/0042098042000178690.

Shukla, V. and P. Waddell. 1991. Firm location and land use in discrete urban space: A study of the spatial structure of Dallas-Fort Worth. Regional Science and Urban Economics, 21(2):225-253. doi: 10.1016/0166-0462(91)90035-L.

Taylor, M. and B. Asheim. 2001. The concept of the firm in economic geography. Economic Geography, 77(4):315-328. ISSN 00130095. doi: 10.1111/j.19448287.2001.tb00167.x.

Teece, D. 1982. Towards an economic theory of the multiproduct firm. Journal of Economic Behavior \& Organization, 3(1):39-63. ISSN 01672681. doi: 10.1016/01672681(82)90003-8.

van Dijk, J. and P. H. Pellenbarg. 2005. Firm relocation decisions in the Netherlands: An ordered logit approach. Papers in Regional Science, 79(2):191-219. ISSN 10568190. doi: 10.1111/j.1435-5597.2000.tb00768.x.

van Oort, F. G. 2004. Urban growth and innovation: Spatially bounded externalities in the Netherlands. Aldershot: Ashgate. ISBN 9780754638674.

van Oort, F. G. and R. Ponds. 2007. Relocation of Firms and Growth in Employment. The Hague: Netherlands Institute for Spatial Research.

van Soest, D. P., S. Gerking, and F. G. van Oort. 2006. Spatial impacts of agglomeration externalities. Journal of Regional Science, 46(5):881-899. ISSN 0022-4146. doi: 10.1111/j.1467-9787.2006.00488.x.

van Wissen, L. 2000. A micro-simulation model of firms: Applications of concepts of the demography of the firm. Papers in Regional Science, 79(2):111-134. doi: 10.1111/j.1435- 5597.2000.tb00764.x.

Waddell, P. and G. F. Ulfarsson. 2003. Accessibility and agglomeration: Discrete-choice models of employment location by industry sector. In Conference proceedings of the 82nd Annual Meeting of the Transportation Research Board. Washington, D.C. 